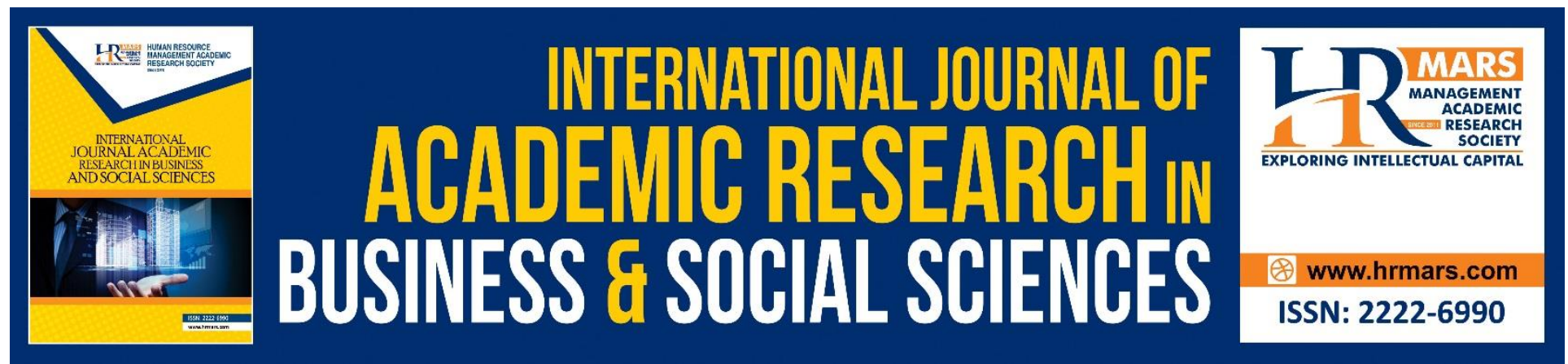

\title{
Impact of E-banking on the Operational Efficiency of Banks in Nigeria
}

\author{
Ibrahim Darazo Rabiu, Sirajo Ladan, Hafiz Ahmed Usman, Murtala Garba
}

To Link this Article: http://dx.doi.org/10.6007/IJARBSS/v9-i2/5527

DOI: $\quad 10.6007 /$ IJARBSS/v9-i2/5527

Received: 02 Feb 2019, Revised: 17 Feb 2019, Accepted: 30 Feb 2019

Published Online: 03 March 2019

In-Text Citation: (Rabiu, Ladan, Usman, \& Garba, 2019)

To Cite this Article: Rabiu, I. D., Ladan, S., Usman, H. A., \& Garba, M. (2019). Impact of E-banking on the Operational Efficiency of Banks in Nigeria. International Journal of Academic Research in Business and Social Sciences, 9(2), 136-145.

\section{Copyright: (C) 2019 The Author(s)}

Published by Human Resource Management Academic Research Society (www.hrmars.com)

This article is published under the Creative Commons Attribution (CC BY 4.0) license. Anyone may reproduce, distribute, translate and create derivative works of this article (for both commercial and non-commercial purposes), subject to full attribution to the original publication and authors. The full terms of this license may be seen

at: $\underline{\text { http://creativecommons.org/licences/by/4.0/legalcode }}$

\section{Vol. 9, No. 2, 2019, Pg. 136 - 145}

Full Terms \& Conditions of access and use can be found at http://hrmars.com/index.php/pages/detail/publication-ethics 


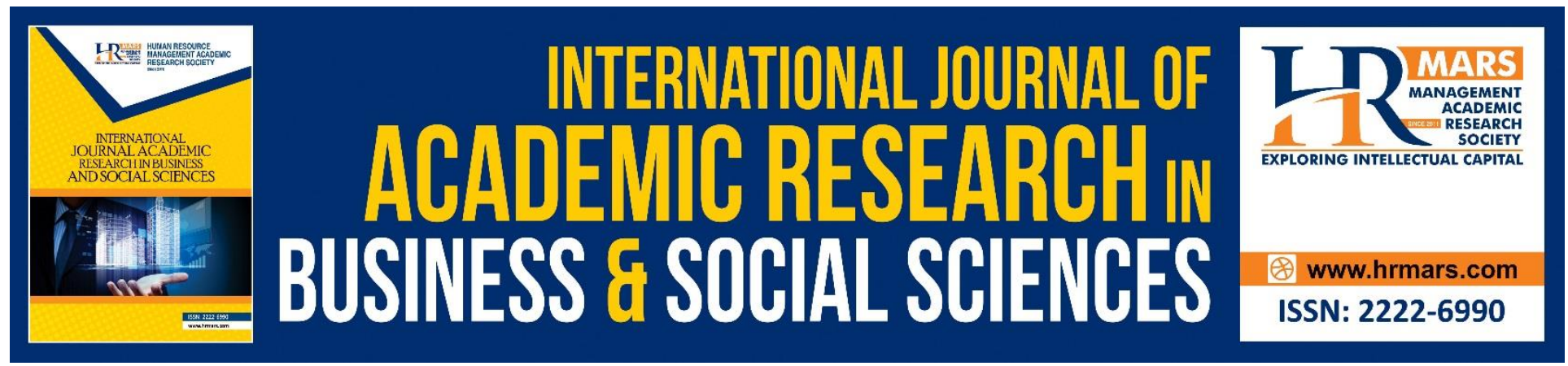

\title{
Impact of E-banking on the Operational Efficiency of Banks in Nigeria
}

\author{
Ibrahim Darazo Rabiu
}

Department of Accounting \& Finance Technology, Abubakar Tafawa Balewa University, Bauchi-Nigeria.

Email: rdibrahim@atbu.edu.ng.

\section{Sirajo Ladan}

Department of Accounting \& Finance Technology, Abubakar Tafawa Balewa University, Bauchi-Nigeria.

Email: sirajoladan84@gmail.com

\section{Hafiz Ahmed Usman}

Department of Accounting \& Finance Technology, Abubakar Tafawa Balewa University,

Bauchi-Nigeria. Email: elhafizlame@gmail.com

\section{Murtala Garba}

Department of Accounting \& Finance Technology, Abubakar Tafawa Balewa University,

Bauchi-Nigeria. Email: rdibrahim@atbu.edu.ng.

\begin{abstract}
The research has been conducted on the impact of E-banking on the operational efficiency of Banks in Nigeria, A case of Diamond Bank Plc, Bauchi branch, Nigeria. The objective of the study is to determine the impact of e-banking on the operational efficiency of banks in Nigeria. The research is a quantitative research which used primary sources of data collection. Questionnaires were used to obtained data. 138 questionnaire were distributed among customers of the Bank and the data collected where analysed using regression analysis. It is clear from the findings that, the use of E-banking (Internet and Mobile banking) by the banks has improved the efficiency of these Banks, in terms of providing efficient services to customers electronically, reduces time taken to serve customers, allows new customers to open an account online, customers have easy access to their account at all the time 24/7. Furthermore, E-banking provides access to customer's information from the data base and cost of cheque and postage was eliminated using E-banking. It is recommendation; the Banks should try to update and improve their internet banking platform, as it has significant positive impact on the operational
\end{abstract}


efficiency of banks. Also, Biometric ATMs should be introduced to reduce fraud using ATM Cards, as it is use in other countries like USA among others.

Keywords: Bank, Electronic Banking, Internet banking, mobile banking and Operational Efficiency of Bank.

\section{INTRODUCTION}

The Banking sector of every country is an important sector that has been used to implement monetary policy and other economic policies of the government. The Bank as the implies and used for the purpose of this research can be defined "as a financial institution that is established by the law of the country to accept deposit from the surplus segment of the economy, and making payment on behalf of its customers and receive payment on its behalf". According to Pary (1970), he describes a bank as an establishment, which deals in money receiving it on deposit from customer, honoring customer drawing against such deposit, on lending or investing the surplus until it is required.

A Bank is an organization whose principal operations are concerned with the accumulation of temporary idle money of the general public for the purpose of advancing to others. Ordinary banking business consist of changing cash for bank deposit and Bank deposit to cash, transferring bank deposit from one person or corporation to another, giving bank deposit in exchange for bill of exchange, government bond (Adekaye, 1984).

Moreover, in the 21st century or information edge, Banks are faced with the challenges of using Information and Communications Technology (ICT) in providing banking services. This is what led to E-banking. Banks cannot ignore information system because it plays a critical role in their competitive edge both locally and globally, and cash flow is linked to their adoption information system (laudon \& laudon 1991). E- Banking can be define as a means where by banking business is transacted using automated processes and electronic devices such as personal computer, telephones, facsimiles, internet card payment and other electronic channels (Report of Technical Committee on e-banking CBN, 2003). Agene (2009), urges that, the adoption of e-banking by banks in many nation recently, of course has its roots in the fundamental role of Banks in financial intermediation and resources allocation.

The old method of manual banking has been replaced by the electronic method, where almost all the banking services are now available using electronics. E-Banking is gaining acceptance among customers. The research will look at how these e-banking improved the operational efficiency of the banks in Nigeria.

The efficiency here means the use of resources to achieve the goals with a lower or minimal cost, which is providing services to customers with a little cost to generate profits. According to Adekaye (1984) the secret of successful banking is to distribute resource between the various forms of assets in such a way as to get a sound balance between liquidity and profitability, so that there is cash to meet the claims and at the same time have enough profits for its shareholder. The objective of the study include; To determine the impact of e-banking on the operational 
efficiency of Banks in Nigeria and to identify the different e-banking services offered by banks in Nigeria.

The bankers business is to take the debts of other people to offer his own in exchange and there by create money (layi, 2008). Also, Woherem (2000) claims that only banks that overhaul the whole of their payment and delivery system and apply information and communication technology to their operations are likely to survive and prosper in the new millennium. Banks have used electronic channels for years to communicate and transact business with both domestic and international corporate customers (Auta, 2010).

Based on that, he further advised that banks should re-examine their services and delivery system in order to properly position themselves within the frame work of information and communication technology. The computer has changed the way banks offer their retails banking to customers, which makes it convenient to customers, even though some have reservations regarding the retails banking. According to Oluyenat (2001), electronic banking is the provision of banking services by financial institution to their customers in electronic devices. Electronic Banking is defined as the use of computers to carry out banking transactions such as withdrawals through cash dispensers or transfers of funds at a point of sale (Ibrahim, 2009).

The hypotheses developed by the researcher for the purpose of the research were as follows: Ho Internet banking has no significant impact on operational efficiency of banks in Nigeria. Ho Mobile banking has no significant impact on operational efficiency of banks in Nigeria and Ho Internet banking and Mobile banking has no significant impact on operational efficiency of banks in Nigeria.

\section{REVIEW OF RELATED LITERATURE}

This aspect of the paper will provide or review some literatures on E-banking, types of E-banking, E-banking Model, Operations of a Bank and CBN guidelines on E-banking.

Agene (2009) viewed that, the adoption of e-banking by banks in many nation recently of course has its roots in the fundamental role of banks in financial intermediation and resource allocation. The use of smart cards in Nigeria commenced in the late 1990's, when the CBN granted an approval to a bank in the country in 1996 to introduce a financial product (a close system electronic purse) known as Electronic Smart Card Account (ESCA).) The pioneer effort of this bank was followed in 1997 with the introduction to pay card by another banks in the system.

In 1998, the CBN gave approval to a company floated by a consortium of licensed banks to produce and manage cards issued by member banks. Another consortium of more than 20 banks under the auspices of General Nigeria Limited also got approval to introduce the smart pay scheme.

In the last ten years back, a member of banks have introduced quality electronic based (technology

drivers) product such as telephone banking, PC banking, online banking via internet, master card, the value card and mobile banking in their attempt to complement the derive for an efficient payment system for the country. Banks have the choice to offer their banking services through various electronic distribution channels such as internet technology, video banking technology, telephone banking technology, and Wireless Access Protocol Technology (WAPT). E-banking is 
about using the infrastructure of the digital age to create opportunities both locals and global. Ebanking enables covering the transaction cost, and the creation of new types of banking opportunities that address the barriers of time and distance. The benefit of e-banking comprises a broad range of functions which include: e-mail improves communication between individuals, external parties and between banks. The availability of online information provide bankers and customers with a powerful device for investigate/research, banks can provide information and service online, where customers can pay for and receive. Banking processes are considered more efficient and relatively cost effective by integrating other aspect of banking operation such as treasury management and financial control.

Banks in Nigeria must understand and appreciate that our banking industries now exist in a globalized world. Therefore, they should strive to provide local and global banking product and services using the infrastructure in the global village. The current e-banking applications uses the internet, that is online Banking, which allows customers to get current account balance at any time and it is providing communication and flexibility for customers.

According to Al-Smadi (2012), Electronic Banking enhance the development of the Banking system, and it is considered as strategic weapon for Banks. However, it cannot be achieved without customers patronage, hence, such bank should encourage patronage of electronic banking products.

\section{Types of Electronic Banking in Nigeria}

The e-Banking consist of the following;

Mobile Banking, Internet Banking, Telephone Banking, and Electronic Cards etc.

\section{Internet Banking}

The internet banking has to do with providing banking transaction such as fund transfer, payment for goods and services, Account enquiry, e.t.c on the internet, using electronic devices like computers without visiting the Bank. The e-commerce is greatly enhanced by the internet banking and is mostly used to effect payment, internet banking also uses the electronic card infrastructure for executing payment instruction and for final settlement of goods and services over the internet between the merchant bank and the customer. The common internet payments are for consumer's bills payment for conference and purchase of air ticket through the use of website of the merchant banks.

Moreover, internet Banking refers to system that enables customers to access account and general products and services from anywhere in the globe.

According to Deyong, (2001) the pure play internet banking has become with the concept of "virtual Banks" representing the provision of banking service without physical office but with location on the internet. Example of such virtual Banks in the USA include e-bank (www.ebank.com); first internet bank of Indian (www.firstib.com); Gay and Lesbian Bank (www.glbank.com); market place bank cumu.metbank.com. Moh'd (2010), concluded that, the following strategies would help in consummating greater adoption of internet banking; enhanced salience of internet banking to customers, banking needs, greater compatibility of internet to customers banking norms and lifestyle, less complex and easy to use system that does not require 
a lot of mental and physical efforts to provide banking task and opportunity for adapters of internet banking to experiment with the system before making any long-term commitment.

\section{Mobile Banking}

Mobile Banking involve the use of mobile phones for settlement of financial transaction, it support personal transfer with immediate availability of funds for the beneficiary. Mobile payment use the card infrastructure for movement of payment instruction as well as secure SMS messages for confirmation of receipt to the beneficiary, as it is meant for low value transaction where speed of completing the transaction is key, and has a very exciting potential within Nigeria, given the low infrastructure requirements and a rapidly increasing mobile phone prediction. The services under this type E-Banking include; Account enquiry, funds Transfer, recharge phones, bill payment and changing of passwords which are now offered by some banks in Nigeria; e.g Diamond Bank Plc. e.t.c

According to Sulaiman, (2007) it was reported that twenty one institutions offered these (Mobile Banking) services with very low patronage by the customers for funds transfer. Furthermore, recharge phone service was provided by sixteen (16) banks fall within low and medium range respectively, these signifying low patronage. Moreover, from this study, it is clear that the mobile banking is now gaining acceptance in the country as many customers are using mobile banking.

\section{The Theoretical Framework}

The theoretical framework for the research is An E-banking model (framework) which was built on the Traditional E-commerce dimension. The basic elements of customer experience found in traditional E-commerce they include; (a) Navigation that is, the ability to access and move around the site (web site).

(b) Information, or the ability to provide enough information to assist customers makes a purchase decision. (c) Support, which is providing customers support regarding various aspect of product or services and be able to answer question promptly. (d) Logistic, which is handling, packaging and delivering the physical goods or services to the customer and arranging for payment ( Seteriou \& Zenios, 2003).

The four element mentioned in the traditional E-commerce dimension, is expected to have a positive impact on customer loyalty, in turn on long term growth and profitability of Banks ( Heskelt, Sasser \& Schlesinger, 1997)

Moreover, an E-banking framework that has been developed by Stavios and Zenios (2003) was built on the traditional E-Commerce dimension. Ones of the elements, which are Navigation is still an important element in E-banking framework. Another element of traditional E-Commerce is information handling; where financial services such as the once provided by bank requires continuously update, relevant and complete information available to the right customers.

Another element in the E-banking framework is support, were some believe that, a successful site will result in minimal customers support request. This has not been the experience of many successful internet firms, which have recognized the importance of customer support within Eservices. In E-banking, however, the dimension of logistics was replaced with financial intermediation and the management of risk (Stavios \& Zenios, 2003). 


\section{Operations of a Bank}

Prior to the introduction of the concept of universal banking, commercial banks carry out ordinary retail banking services. However, the concern here is to briefly explain the major operation at the branch level.

Essentially, branch operation is basically classified in to two broad major activities. The operation is made up of the back office operations and front office operation (Ahmad, 2007). The use of electronic banking has transformed those operations to the advantage of the bank.

\section{OPERATIONAL EFFICIENCY OF BANKS IN NIGERIA}

The efficiency as used for the purpose of this research means the ability of an organization to achieve its goal using the available resources at minimal cost. Moreover, the operational efficiency of Bank, simply means the ability of a Bank to provide all the banking services using it's available resources to achieve its goals or objectives. Also, this operation as used in this research is referring to the front office and Back office operation. The operational efficiency of a bank is determined by using or looking at the extent to which Banks improved in such operations to deliver qualitative services to their customers. Not only that, but also, the ability of the Bank to use the e-Banking facilities to improve on their operational efficiencies, which involved front office, that is, those operations that are carried out in order to attend to customers directly by the teller of a Bank at the counter and the Back office operation which is the activities and where all transfers are made at branch level, especially the Banks under study. Meanwhile, it is important to categorically stated here that, the E-banking has change the way these Banks (Diamond Bank plc.) operate such basic operation of the Banks. Nowadays, the back office operation are mostly carried out using computers intranet and in some cases using internet to transfer funds from one account to another and other back office operations. Also, the front office operation are now available using E-banking facilities, such as ATM, Mobile phone and Telephone to provide services to customers. That is why Agene (2009), urges that, the adoption of e-banking by banks in many nation recently, of course has its roots in the fundamental role of Banks in financial intermediation and resources allocation.

Moreover, Banks are making what it seen like huge investment on technology to maintain and upgrade their infrastructure in order not only to provide new electronic information base services but, to manage their risk position and pricing (Rogers, 2009).

Dhanapals and Ganeson (2012), have identified the following to be the ways of improving operational efficiency of Banks; innovation product design, such as zero base account, ATM card, mobile banking etc, Development of Technology, such as powered ATM technology that will save cost, reducing overstaffing and strategies with banks financial institution that could increase revenue generation and in turn increase productivity of the banks and most importantly corporate governance; here the transparency of the operations of the banks is receiving serious attention because of the corporate governance. Therefore, Banks should adhere to the above points in order to improve on the operational efficiency of their Banks. 


\section{METHODOLOGY}

The research is quantitative research that made use of primary source of data, which are questionnaires in the analysis. The data were drawn using the questionnaire to actually find the accurate data and simple random sampling was use to draw the sample for the studies, where 150 questionnaires were distributed and 138 were obtained from the respondents, Moreover, IBM SPSS's regression analysis was used to analyse the data obtained. This is to enable the researcher to determine the impact of electronic banking (Internet and mobile banking) on operational efficiency of Banks in Nigeria, especially at this information age.

\section{RESULT AND FINDINGS}

The research included 138 respondents, where 72 are male which constituted about $52.2 \%$ while the remaining 66 were female that made up of $47.8 \%$ of the total respondents. With regard to the age of the respondents; $18-25$ years are only 15 that is $10.9 \%, 26-35$ years are 38 respondents which constituted about $27.5 \%$, 36-50 years were 35 respondents which is $25.4 \%$ and $51-70$ years are 50 that is $36.2 \%$ of the total respondents. The educational level of the respondents indicated that 24 respondents comprises about $17.4 \%$ have primary - secondary certificate, polytechnic college has 65 respondents which is about $47.1 \%$ and 49 respondents went to university which made up of $35.5 \%$ of the total respondents.

\section{Validity and Reliability}

It is important for any good research to test the validity and reliability of the instrument used. The validity was tested using IBM SPSS's factor analysis with the help of exploratory factor analysis, where principal component analysis was used. The first construct is internet banking, where sample size is 138 which is considered moderate according to Hair, Blank and Anderson (2010) and Tabanich and fidell (2007). The KMO is 0.566 which is above the minimum standard of 0.50 and considered suitable. Bartett's test of Specricity Appex Chi-square is 250.430, df is 15 and significant is 0.000 . The communalities for all the six items as found to be above minimum standard of 0.50 . also, some of the correlation coefficient were above 0.30 . Therefore, all the six items are valid to measure the construct. In the case of mobile banking, the sample size is also 138 and KMO is 0.407, Bartett's test of Specricity Appex Chi-square is 173.033, df is 21 and significant is 0.000 . The six out of seven items have communalities of 0.50 and above, except MB5 which has 0.467. Moreover, MB1, MB2, MB3, MB4, MB6 and Mb7 are the only items to measure the construct. With regard to operational efficiency of banks, the sample size is $138, \mathrm{KMO}$ is 0.621 which is considered adequate because it is above the minimum standard of 0.50. Bartett's test of Specricity Appex Chi-square is 378.717, df is 21 and significant is 0.000 . All the seven items have communalities of above 0.50 , as such all the seven items are valid to measure the construct The Reliability of scale (internet banking, mobile banking and operational efficiency) was investigated using IBM SPSS's Cronbarch Alpha reliability (Cronbarch,1951). The estimated range of the cronbarch alpha between 0 to 1 , with 0.7 being normally considered the minimal acceptable level of the reliability. The result of the reliability of the variables showed a cronbarch alpha of 0.519 using 20 items. It's indicated that, the items in the scale have internal inconsistency because, the cronbarch alpha is less than 0.7. Under Internet banking (IB), the cronbarch alpha is 
0.0.480, which is below the minimum standard of 0.7 , as such there will be inconsistency of result when items are used in different condition. In the case of mobile banking, the cronbarch is 0.674 , which is also below the minimum standard of 0.70 . Therefore, inconsistency of result may prevail when items are used in different condition. Under operation efficiency of banks, the cronbarch alpha is 0.459 and is below the minimum standard of 0.70 and is indicating internal inconsistency if the items are going to be use in another different condition.

\section{Regression Analysis/Result}

Before the regression analysis some of the regression assumption where tested and hypothesis were also tested using multiple regression.

\section{Normality test}

There are many ways to test normality. But in this study histogram and a Normal p-p plot was used. From the normal P-P plot, it shows that, the data where normal, because the data were arranged on the diagonal or close to diagonal line.

\section{Correlation Analysis}

The inter-construct correlation was found for the constructs; Internet Banking (IB) is 0.354, Mobile Banking (MB) is 0.956, Operational Efficiency of Banks (OEB) is 0.160 which are recommended according to Pallant (2007). It can be concluded that, some of the variables were correlated at 0.01 level 2 tailed.

\section{Multicolinearity Test}

Multicolinearity was tested using tolerance and VIF. It can be seen from (coefficient table) that the tolerance value for IB is 0.088 and $M B$ is 0.088 and VIF for IB is 1.143 and $M B$ is 1.143 as such there was no multicolinearity among the independent variables. All the tolerance value were not more than 0.10 and VIF value is not more than 10, as such there was no multicolinearity among the variables (Pallant, 2007).

\section{Hypothesis Testing Hypothesis One}

Internet banking has significant impact on operational efficiency of Bank.

The $p$ value is 0.048 , which indicates statistical significant, because $p$ value is less than 0.05 . It can be concluded that, internet banking has significant impact on operational efficiency of banks. Therefore, the alternate hypothesis is accepted and null hypothesis is rejected.

Hypothesis Two

Mobile banking has significant impact on operational efficiency of Bank.

The $p$ value is 0.0514 which shows a statistical insignificant of mobile banking on operational efficiency of bank, because the calculated $p$-value is greater than 0.05 . It can be concluded that, there is a statistical insignificant of mobile banking on operational efficiency of bank. 


\section{Hypothesis Three}

Internet and mobile banking have statistical significant impact on operational efficiency of bank. The calculated $\mathrm{R}$ is 0.290 that is, Internet banking and mobile banking explained $29.0 \%$ of operational efficiency of bank, whereas the remaining $71 \%$ is explained by other variables that are not included in the model. The $p$ value is 0.141 , which is greater than 0.05 and indicates a statistical insignificant of internet banking and mobile banking on operational efficiency of bank. Therefore, alternate hypothesis is rejected and null hypothesis is accepted. It can be concluded that internet banking and mobile banking have statistical insignificant on operational efficiency of bank.

\section{CONCLUSION AND RECOMMENDATIONS}

\section{Conclusion}

The investment in E-banking require huge amount of fund and banks are now investing in ebanking to ensure that, they provide their customers with modern banking services. It is concluded that, internet banking has statistical significant impact on operational efficiency of bank in Nigeria. On the other hand, mobile banking has statistical insignificant on operational efficiency of bank in Nigeria. The products of e-banking that is use by the Banks include; internet banking and mobile Banking etc., should be improved so that, the expected length of time in the banking hall will reduce and efficient service will be delivered to customers. Moreover, it is concluded that internet and mobile banking have statistical insignificant on operational efficiency of bank in Nigeria.

Therefore, this is in line with what Anyanwaokoro (2001) stipulated, the settlement of financial obligation are now done by the use of electronic gadgets such as computers, ATMs and Telex, instead of currency notes and coins. The introduction of e-banking in Nigeria has also contributed significantly to the income earn by the Banks, because, by the way of charges or fee Bank are gotten from these e-banking services provide to customers.

\section{Recommendations}

Based on the conclusion drawn from the research findings, the following recommendations were made;

1. Bank should ensure adequate security of personal information of their customers, as such information if not kept secretly could be used by criminals in the Information Technology to have access to customers account.

2. Banks should also, improve the network facilities and ensure that, the network or connectivity is always available for the Banks to connect to their branches at all time. As failure to improve or maintain the network facilities and others, will affect the Bank, since customers are now rating Banks base on their electronic Banking products they have.

3. Banks in Nigeria should try as much as possible to controlled E-fraud (internal \& external) which will increase confidence in the Banking sector as a whole. Like using Biometric ATMs as use in other countries such as Unites state of America.

4. It is recommended that, further studies to include other aspect of E-banking that are not included in this research and also increase the population of the study. 


\section{REFERENCES}

Adekanya, O. A. (2010). The law and practice $f$ banking in Nigeria. Ibadan. University of Ife press. Adekaye, F.(1984) The element of banking in Nigeria, Ibadan. Graham Burn,.

Agene, C. E. (2009) Electronic banking in Nigeria: Conceptual issues and supervisory framework. Bullion publication of the central bank of Nigeria (CBN), 24(4), 67-74.

Agene, C.E. (2009). Network Technologies and Electronic payment system Security, Department of computer science. Enugu. Nmanbi Azikwe university press.

Al-Smadi, M. O. (2012). Factors affecting the Adoption of E-banking. An analysis of the perspectives of Bank's Customers. International Journal on Business and Social Science. 3(17), 302.

Anyanwaokoro, M. (2001). Element, Practice and Processes of Banking Operations. Enugu, Hossana Publication.

Deyong, R. (2013). The Financial Performance of Pure play internet banking. Economic perspective federal reserve Bank of Chicago Electronic Banking System. 2001. Retrieved from http://www.electrobank.com.eba.eb.htm. on 10/12/2013.

Dhanapal, C. and Ganesan, G. (2012). Measuring operational efficiency of Public Sector Banks in India. A paper presented at the 2012 International Conference on Business and Management.6-7 September, 2012, Phuket- Thailand.

Floh, A. \& Treiblmaier, H. (2006) What keeps the E-banking customer loyal?, A multi group analysis of the moderating role of customers characteristics on E-loyalty in Financial service industry. Journal of Electronic Commerce Research. 7(2),106.

Layi, A. (2008). Law and practice of Banking. Lagos. Heineman Education Books (Nig) Plc,.

Moh'd, N. S. (2010). An empirical study of factors affecting the internet banking Adoption among Malaysian customer's. Journal of internet Banking and Commerce. 5(2), 9-10. Mundu, H. (2010, May 21). Importance of e-payment on Clearing and Forwarding.

Daily Sun, P.A.8.

Oluyenut, E. (2001) Development of electronic Banking in Nigeria. The Regulatory/Supervisory challenges. NDIC Quarterly publication. 11(34).

Sulaiman, A. (2007). Report on the Survey of Developments in the e-payments and Service Products of Banking and other Financial Institutions in Nigeria, Central Bank of Nigeria Library, 6-14. 